\title{
REMOTE SENSING TECHNIQUES AS A TOOL FOR ENVIRONMENTAL MONITORING
}

\author{
Kamil Faisal $^{\mathrm{a}, \mathrm{b}, *}$, Mohamed AlAhmad ${ }^{\mathrm{c}}$, Ahmed Shaker ${ }^{\mathrm{a},}$ \\ ${ }^{a}$ Department of Civil Engineering, Ryerson University, 350 Victoria Street, Toronto, Ontario, M5B2K3 Canada -(ahmed.shaker, \\ kamil.faisal)@ ryerson.ca \\ ${ }^{b}$ Department of Geomatics, College of Environmental Design, King AbdulAziz University, Kingdom of Saudi Arabia \\ ${ }^{\mathrm{c}}$ Environment public authority, Kuwait
}

Commission VIII, WG VIII/8

KEY WORDS: Remote Sensing, Multi Temporal Images, Landsat Images, Landfill Sites Monitoring, Land Surface Temperature, Landfill Gas

\begin{abstract}
:
The disposal of the solid wastes in landfill sites should be properly monitored by analyzing samples from soil, water, and landfill gases within the landfill site. Nevertheless, ground monitoring systems require intensive efforts and cost. Furthermore, ground monitoring may be difficult to be achieved in large geographic extent. Remote sensing technology has been introduced for waste disposal management and monitoring effects of the landfill sites on the environment. In this paper, two case studies are presented in the Trail Road landfill, Ottawa, Canada and the Al-Jleeb landfill, Al-Farwanyah, Kuwait to evaluate the use of multi-temporal remote sensing images to monitor the landfill sites. The work objectives are: 1) to study the usability of multi-temporal Landsat images for landfill site monitoring by studying the land surface temperature (LST) in the Trail Road landfill, 2) to investigate the relationship between the LST and the amount of the landfill gas emitted in the Trail Road landfill, and 3) to use the multi-temporal LST images to detect the suspicious dumping areas within the Al-Jleeb landfill site. Free archive of multi-temporal Landsat images are obtained from the USGS EarthExplorer. The Landsat images are then atmospherically corrected and the LST images are derived from the thermal band of the corrected Landsat images. In the Trail Road landfill, the results reveal that the LST of the landfill site is always higher than the air temperature by $10^{\circ} \mathrm{C}$ in average as well as the surroundings. A correlation is also observed between the recorded emitted methane $\left(\mathrm{CH}_{4}\right)$ from the ground monitoring stations and the LST derived from the Landsat images. Based on the findings in the Al-Jleeb landfill, five locations are identified as suspicious dumping areas by overlaying the highest LST contours generated from the multi-temporal LST images. The study demonstrates that the use of multi-temporal remote sensing images can provide supplementary information for landfill site monitoring.
\end{abstract}

\section{INTRODUCTION}

Municipal solid waste management is a critical issue for urban management and city planning (Schubeler, 1996). The main purpose of waste management is to provide sufficient protection to the environment and the general public from the risky effects of waste (Yahaya et al., 2011). There are number of optical remote sensing sensors that are commonly used for Earth observation and environmental monitoring. Optical remote sensing sensors acquire images of the Earth surface by recording the solar radiation reflected from targets on the ground. Applications of remote sensing in environmental monitoring of the landfill sites aim to map its spatial extent, surrounding vegetation cover, and chemical composition of the surface (Slonecker et al., 2010). These data can provide valuable information for environmental impact assessment within landfills and the surrounding areas. There are number of researches using satellite remote sensing images for landfill site monitoring.

Nas et al. (2010) demonstrated a case study in the City of Konya, Turkey, for appropriate site selection for the landfill, using the GIS and multi-criteria evaluation (MCE). The ArcGIS ArcMap 9.0 and its extensions can be customized to build MCE. Eight GIS layers were acquired for this site selection, including the urban areas, land use/land cover, land slope, archaeological sites, transportation routes, local wells, and irrigational canals. Each layer was ranked with different weights where 0 indicated an unsuitable area and 10 indicated the most suitable area. The final map shows all the suitable locations for the landfill site for the different categories. The categories were classified as: $6.8 \%$ were the most appropriate, $15.7 \%$ were appropriate, $10.4 \%$ were moderately appropriate, $25.8 \%$ were poorly appropriate, and $41.3 \%$ were inappropriate. At the end of the analyses, three locations were identified as the most appropriate landfill site locations for the City of Konya.

Ottavianelli et al. (2007) introduced the Synthetic Aperture Radar (SAR) interferometric products and hypersepctral data to monitor the Brogborough landfill located midway between Milton Keynes and Bedford in the U.K. The study used the ground-based SAR (GB-SAR) system to measure the microwave signals for the landfill site. The measurements of capped area and the open cells were conducted in the landfill site for a comparative analysis of angular measurements of polarizations. Moreover, coherence (or decorrelation) and SAR backscatter signal method were used to identify the dumping areas. The study demonstrated that the decorrelation method is of particular use to detect the properties and characteristics of the surface of the landfill, i.e., surface roughness, soil moisture affected by topography, speckle, and wave polarization. The 
results showed that high decorrelation and backscatter values can be an indication of the suspicious location of waste deposits

Another research was conducted in the City of Venice, Italy (Biotto et al., 2009). The main goal of this case study was to detect and identify uncontrolled landfill sites. Remote sensing and GIS techniques were used to determine these uncontrolled landfill sites. The datasets included the IKONOS satellite images acquired in 2001 and a 2000 land cover map. Similar to the study of Silvestri and Omri (2008), the Maximum likelihood classification technique was applied to detect the locations and conditions of the landfills by classifying the study areas into stressed vegetation, authorized landfill sites, and industrial sites. Road networks for easy access roads and a low population density were further identified using the GIS. The results showed that the integration of remote sensing techniques and GIS maps can be used efficiently to narrow down suspicious locations of uncontrolled landfill sites (Biotto et al., 2009).

Previously, Mirtorabi (2010) conducted a preliminary analysis on the Trail Road landfill site by using four Landsat images acquired in different years and different seasons. However, the work focused on the use of NDVI and LST to investigate the contamination process within the landfill site and the surrounding vegetation. In this study, an in-depth analysis was carried out in the Trail Road landfill by analyzing more remote sensing Landsat images and improving the quality of the derived LST using the atmospheric correction process.

\section{BACKGROUND OF THE LANDFILL SITES}

\subsection{The Trail Road Landfill, Ottawa, Canada}

The Trail Road landfill site is located in Ottawa City, Ontario, Canada $\left(45^{\circ} 14^{\prime} \mathrm{N}, 75^{\circ} 45^{\prime} \mathrm{W}\right)$ as shown in Figure 1 . The Trail Road landfill was constructed in December 1978. The completed operation of the adjacent Nepean landfill was the reason behind the establishment of the Trail Road landfill site. The new area acquired on the North side of the Nepean landfill site in March 1975 was designated to be the new landfill site. The Trail Road landfill site started to accept solid waste in 1980 to the present. Trail Road landfill contains four stages developed sequentially beginning at Stage 1 (farthest to the East) and moving Westward to Stage 4 (see Figures 1). The total area of the Trail Road landfill site is approximately 2.02 $\left(\mathrm{km}^{2}\right)$ surrounded by farmlands, Highway 416 and some light industry. The Trail Road landfill is considered the primary disposal site for municipal solid waste for the City of Ottawa. The Trail Road landfill site is a municipal non-hazardous landfill that only accepts residential garbage, construction, commercial, institutional, and light industrial waste (Dillon Consulting Limited, 2008).

\subsection{The Al-Jleeb Landfill, Al-Farwanyah, Kuwait}

The Al-Jleeb landfill site is considered the largest existing landfill site in the City of Al-Farwanyah with a total area 5.5 $\mathrm{km}^{2}$ (Schrapp \& Mutairi, 2010). The Al-Jleeb landfill site is located in the City of Al-Farwanyah, Kuwait as shown in Figure 2. The site accepts industrial, commercial, and municipal solid waste. However, construction, demolition, and sludge waste are all located in the south-eastern half of the landfill. The Al-Jleeb landfill site is owned by the Government of Kuwait. The landfill site was licensed by Kuwait Municipality to dispose municipal solid waste in 1980, and the landfill has received about $58 \%$ of the total domestic waste in Kuwait (Schrapp \& Mutairi, 2010). Since 1992, complaints regarding the hazardous effects of the landfill site have been reported due to bad odors emanating (Schrapp \& Mutairi, 2010).

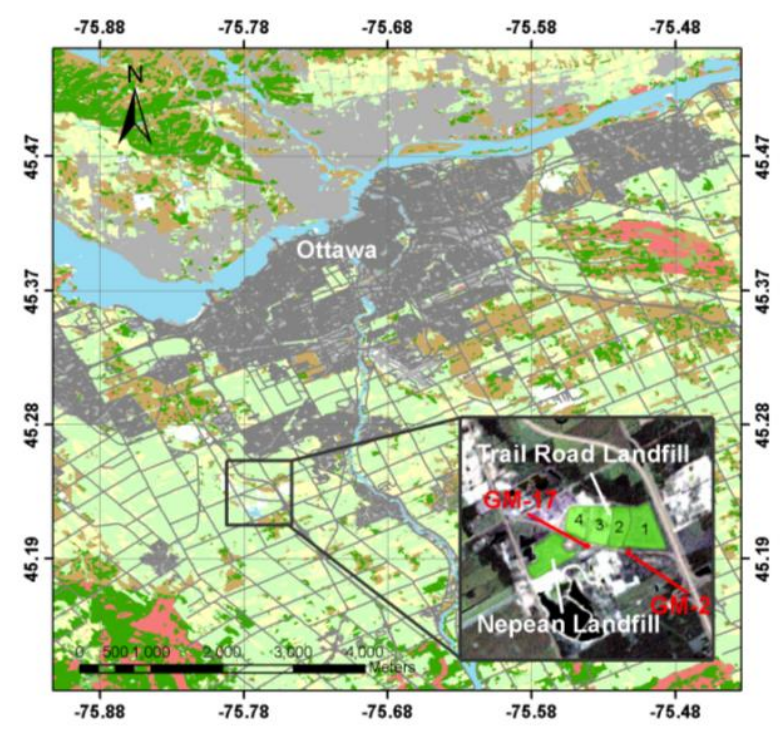

Figure 1. Study area of the Nepean and the Trail Road landfill sites

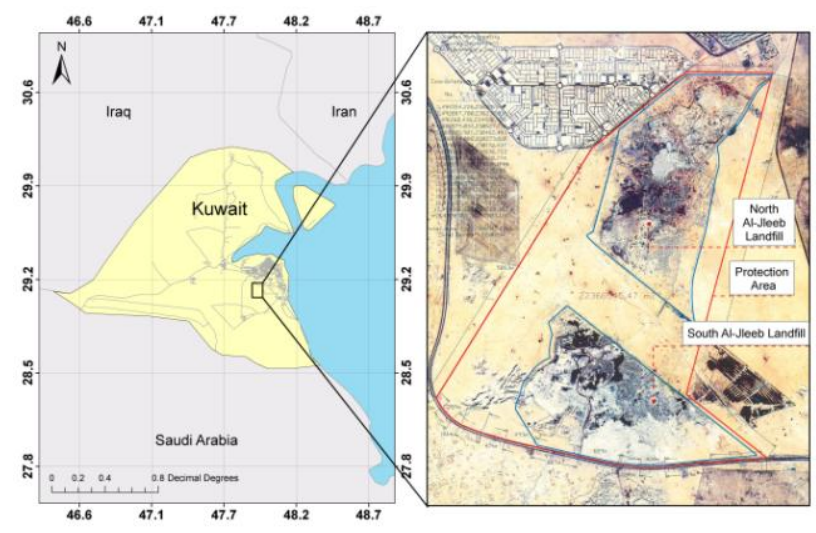

Figure 2. Study area of the Nepean and the Trail Road landfill sites

\section{DATASETS AND METHODS}

\subsection{Datasets}

The study involves two datasets for two case studies:

\subsubsection{Trail Road Landfill}

Trail Road landfill involves two categories of data: 1) multitemporal Landsat satellite images; and 2) landfill gas measurements acquired from ground monitoring wells. Images from years 2007 and 2008 (taken at different acquisition dates, April to October) were downloaded from the USGS Earth as shown in Table 1. The spatial resolution for the Landsat images is $30 \mathrm{~m}$ for the multi -spectral bands and $60 \mathrm{~m}$ for the thermal bands. All these images were imported into PCI Geomatics V10.1, clipped, and then projected into the UTM Zone 18 coordinate system. The atmospheric correction was conducted to retrieve optimal results for the LST, using sensor parameters 
data, (sensor type, acquisition date, sun elevation, sun zenith and pixel size) and weather conditions (air temperature and visibility).

\begin{tabular}{|ccc|}
\hline Acquisition Date & Landsat Sensors & $\begin{array}{c}\text { Air } \\
\text { Temperature }\end{array}$ \\
\hline May $7^{\text {th }} 2007$ & TM & $19.2^{\circ} \mathrm{C}$ \\
May $23^{\text {th }} 2007$ & TM & $23.0^{\circ} \mathrm{C}$ \\
Jun. $15^{\text {th }} 2007$ & TM & $26.6^{\circ} \mathrm{C}$ \\
Jul. $17^{\text {th }} 2007$ & TM & $24.0^{\circ} \mathrm{C}$ \\
Aug. $2^{\text {th } 2007}$ & TM & $31.3^{\circ} \mathrm{C}$ \\
Aug. $27^{\text {th }} 2007$ & TM & $21.4^{\circ} \mathrm{C}$ \\
Sept. $19^{\text {th } 2007}$ & TM & $23.2^{\circ} \mathrm{C}$ \\
Oct. $5^{\text {th }} 2007$ & TM & $23.8^{\circ} \mathrm{C}$ \\
Apr $14^{\text {th }} 2008$ & TM & $6.9^{\circ} \mathrm{C}$ \\
May $25^{\text {th }} 2008$ & TM & $20.9^{\circ} \mathrm{C}$ \\
Jul $12^{\text {th }} 2008$ & TM & $23.7^{\circ} \mathrm{C}$ \\
Aug $20^{\text {th }} 2008$ & TM & $19.9^{\circ} \mathrm{C}$ \\
Sept $5^{\text {th }} 2008$ & TM & $29.0^{\circ} \mathrm{C}$ \\
Oct $7^{\text {th }} 2008$ & TM & $11.2^{\circ} \mathrm{C}$ \\
Oct $23^{\text {rd }} 2008$ & TM & $5.5^{\circ} \mathrm{C}$ \\
\hline
\end{tabular}

Table 1. Multi-temporal Landsat satellite images in 2007 and 2008

All images were used to verify the relationship between the satellite-based and ground-based measurements. The acquisition dates from November to March were neglected due to the weather conditions which could affect data results. The difference in temperature measurements were used to correlate with the emitting landfill gas Methane $\left(\mathrm{CH}_{4}\right)$ measurements acquired at two monitoring stations, GM-2 and GM-17, located near Stages 1 and 3 of the Trail Road landfill. The location of the ground monitoring stations is shown in Figure 1.

\subsubsection{Al-Jleeb Landfill}

In this case study, multi-temporal Landsat $\mathrm{TM}$ and $\mathrm{ETM}^{+}$ images covering the City of Kuwait were downloaded for the last 25 years. However, not all the images were used due to the problem of radiometric quality, i.e., scan line corrector problem. Consequently, only 11 Landsat images were used from 1985 to 2001. All the images were imported into PCI Geomatics V10.1, clipped, and then projected into the UTM Zone 39 coordinate system. Similar to the case study on the Trial Road landfill, the sensor parameters and the weather information (see Table 2) were used for atmospheric correction and computation of LST. The weather information was obtained from the Environmental Public Authority of Kuwait, but some of that data was found to be missing due to the Gulf War in 1991. In this case study, the multi -temporal Landsat images are used to predict suspicious dumping areas within the landfill site.

\subsection{Methodology}

Figure 3 shows the overall workflow for the two case studies (Trail Road landfill and Al-Jleeb landfill) which can be summarized in the following steps. First, the multi-temporal Landsat images were downloaded from the USGS Earth Explorer where the images have been released free to the public since year 2008. Only the thermal band (Band 6 of Landsat TM and Band 61 of Landsat $\mathrm{ETM}^{+}$) are used to determine land surface temperature (LST) in this study.

For the Trail Road landfill site, 16 Landsat TM images are downloaded from years 2007 to 2008 and for the Al-Jleeb landfill, 11 Landsat TM and $\mathrm{ETM}^{+}$images were acquired from years 1985 to 2001 . As the acquired Landsat images cover the area of $185 \times 185 \mathrm{~km}^{2}$, the images were clipped to the landfill sites to improve the performance of data processing. Finally, all the subsets of the images were projected into the UTM coordinate system.

Before computing the LST, atmospheric corrections were conducted for all the multi-temporal Landsat images. The atmospheric correction model (ATCOR2) developed by Richter (1998) was utilized to calculate the transmission and the up and down radiance. Details of the atmospheric correction will be discussed in Section 3.2. To run the ATCOR2 model, weather information (e.g. air temperature, visibility, etc.) were obtained from the Government's national climate and weather data archive. The calibration parameters for Landsat TM and $\mathrm{ETM}^{+}$ sensor (biases and gains) were also required for an atmospheric correction. After conducting the atmospheric correction, the LST was derived from the thermal band of the Landsat images.

The LST for the Trail Road landfill site was compared to the LST of the surrounding areas as well as the air temperature for each of the Landsat images. This comparison was conducted using the GIS zonal analysis, together with the boundary of the landfill site. The LST for the closed stages was also compared to the LST of the active stage as well as the recently closed stage. A preliminary analysis was carried out to investigate the correlation between the LST and the amount of landfill gas. The measurements of methane $\left(\mathrm{CH}_{4}\right)$ from the two monitoring wells (GM-2 and GM-17) were obtained within years 2007 and 2008, and a regression analysis was conducted to derive the relation between these two factors.

For the Al-Jleeb landfill, the multi-temporal LST images (from 1985 to 2001) were imported in the GIS environment for further analysis. Temperature contours (polylines) were generated for each of the LST images by using the raster to vector conversion tool. As the goal for the Al-Jleeb landfill case study aimed at determining the suspicious location of the waste dumping area, the highest temperature of the contours was extracted from the polylines for each of the LST images. The extracted temperature were then overlaid in the GIS environment and the location with high dense overlapping areas was regarded as the possible location for the waste dumping areas in the Al-Jleeb landfill site.

\begin{tabular}{|ccc|}
\hline Acquisition Date & $\begin{array}{c}\text { Landsat } \\
\text { Sensors }\end{array}$ & $\begin{array}{c}\text { Average Air } \\
\text { Temperature }\end{array}$ \\
\hline Jan $13^{\text {th }} 1985$ & TM & $18.5^{\circ} \mathrm{C}$ \\
Dec $29^{\text {th }} 1987$ & TM & $8.5^{\circ} \mathrm{C}$ \\
Jun $12^{\text {th }} 1990$ & TM & $38.0^{\circ} \mathrm{C}$ \\
Sept $27^{\text {th }} 1991$ & TM & $32.5^{\circ} \mathrm{C}$ \\
Oct $29^{\text {th }} 1991$ & TM & $29.0^{\circ} \mathrm{C}$ \\
Feb $28^{\text {th }} 1993$ & TM & $21.5^{\circ} \mathrm{C}$ \\
Apr $07^{\text {th }} 1998$ & TM & $22.0^{\circ} \mathrm{C}$ \\
May $30^{\text {th }} 2000$ & TM & $36.5^{\circ} \mathrm{C}$ \\
Sept $03^{\text {th }} 2000$ & TM & $33.0^{\circ} \mathrm{C}$ \\
May $25^{\text {th }} 2001$ & $\mathrm{ETM}^{+}$ & $34.0^{\circ} \mathrm{C}$ \\
Oct $16^{\text {th }} 2001$ & $\mathrm{ETM}^{+}$ & $27.0^{\circ} \mathrm{C}$ \\
\hline
\end{tabular}

Table 2. Landsat TM and ETM+ Images for the Al-Jleeb Landfill Case Study 


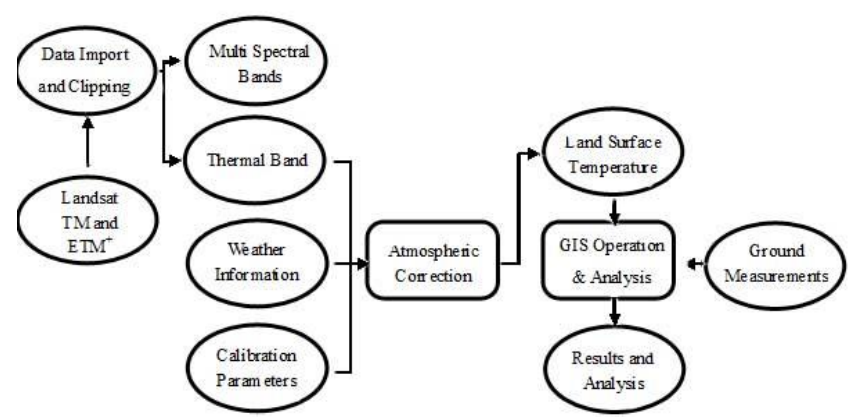

Figure 3. Experimental Workflow

\section{RESULT AND ANALYSIS}

\subsection{Trail Road Landfill}

Figures 4 and 5 show a comparison between the LST and the air temperature for specific dates in 2007 and 2008. In 2007, the LST for the Trail Road landfill in April and June is higher than the air temperature by $10^{\circ} \mathrm{C}$. A drop in the temperature difference is found in July and August, mainly due to relative low sky visibility and haze effects on the remote sensing images. The result may be affected even when the atmospheric correction is applied. The LST for the landfill site is constantly higher than the air temperature by $6^{\circ} \mathrm{C}$ during September and October.

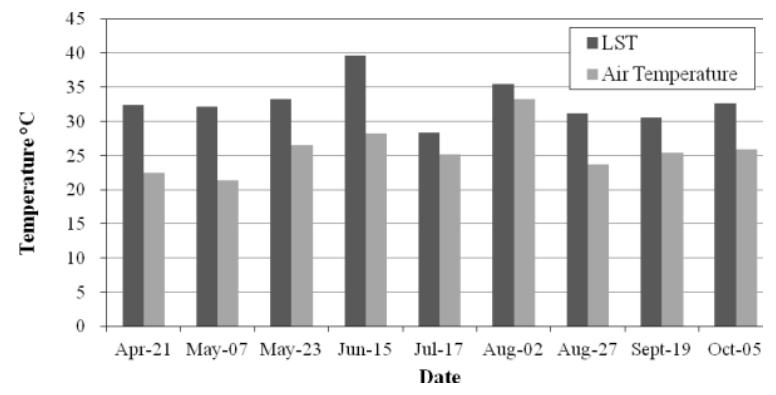

Figure 4. Comparison of LST and the Air Temperature for the Trail Road Landfill in 2007

In 2008, the difference between the LST and the air temperature varied due to seasonal changes. On April 14, the LST was $7^{\circ} \mathrm{C}$ higher than the air temperature and the difference in the temperature was more than $10^{\circ} \mathrm{C}$ during May to August. The temperature difference drops below $7^{\circ} \mathrm{C}$ after September except for the result in October 7th. Based on the results from 2001 to 2009 as well as the results for 2007 and 2008, one can conclude that the LST for the landfill site is always higher than the air temperature.

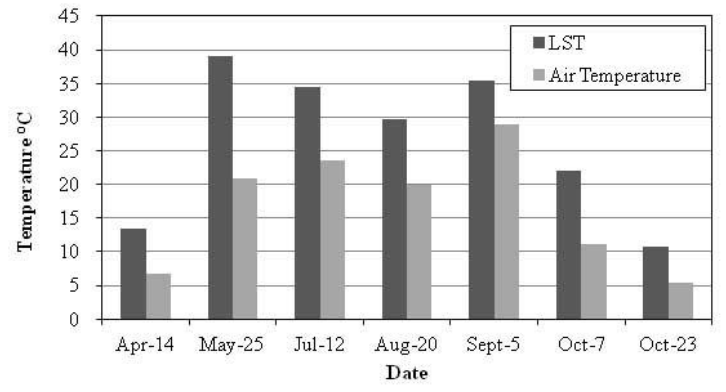

Figure 5. Comparison of LST and the Air Temperature for the Trail Road Landfill for Year 2008

The Trail Road landfill site is monitored by a comprehensive ground monitoring system, which measures and records the amount of landfill gas, the quality of surface and groundwater, and soil contamination. A preliminary analysis was conducted to determine the correlation between the measurements from these monitoring wells and the LST derived from the remote sensing images. Such an analysis has not been performed for the previous literature which adopted Landsat images for landfill monitoring. The measurements of two landfill gas monitoring stations (GM-2 and GM-17) are utilized for this preliminary analysis. The reasons to select these two stations from the total of 28 stations are mainly the availability of the measurements recorded in the annual reports and the well distribution of these stations among Stages 1 to 4 (see Figure 1).

These monitoring wells measure the percentage of emitting methane $\left(\mathrm{CH}_{4}\right)$ and the pressure; the records of $\mathrm{CH}_{4}$ are taken to perform the correlation, as $\mathrm{CH}_{4}$ is the main element of landfill gas. Also, the measurements from the shallow level of the monitoring wells are taken as it is close to the ground level that will be close to the land surface for the calculation of LST. Due to inconsistency between the date of ground measurement and the date of the remote sensing image acquisition, the ground data were linearly interpolated so as to align the dates to the remote sensing image. Correlation analysis is conducted for both 2007 and 2008 by using the regression analysis.

Figures 6 and 7 show the relationship between the percentages of emitting methane recorded in station GM-2 (located at the south of Stage 1) and the LST in 2007 and 2008, respectively. Figures 8 and 9 show the relationship between the percentages of emitting methane recorded in station GM-17 (located at the south of Stage 3) and the LST in 2007 and 2008, respectively. To remove seasonal effects in the derived LST data, the LST value is subtracted from the air temperature, so all the measurements are reduced to the same base. Preliminary analysis revealed that a mid-correlation was observed for both of the ground- monitoring wells in 2008 where $R^{2}$ is 0.573 for GM-2 and $\mathrm{R}^{2}$ is 0.914 for GM-17. However, both stations had low correlation coefficient with the LST measured in 2007 where $\mathrm{R}^{2}$ was 0.066 in GM-2 and $\mathrm{R}^{2}$ was 0.332 in GM-17). In spite of these results, all the fitted regression lines show that the amount of emitting methane has direct proportional relationship to LST.

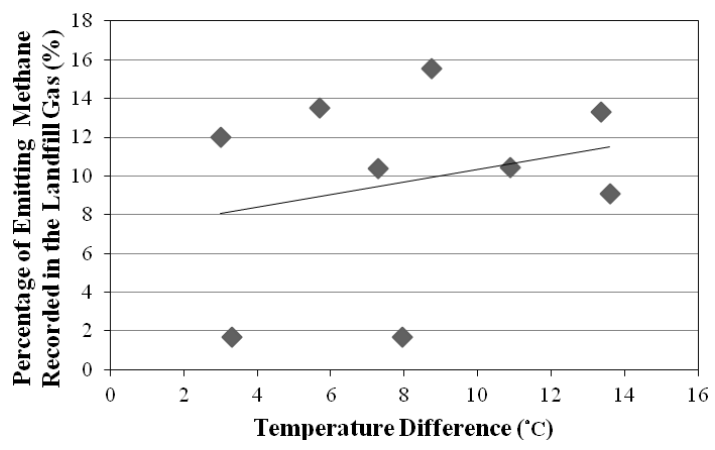

Figure 6. Relationship between the Percentage of Emitting Methane Recorded in GM-2 and the Temperature for $2007\left(\mathrm{R}^{2}\right.$ $=0.066$ ) 


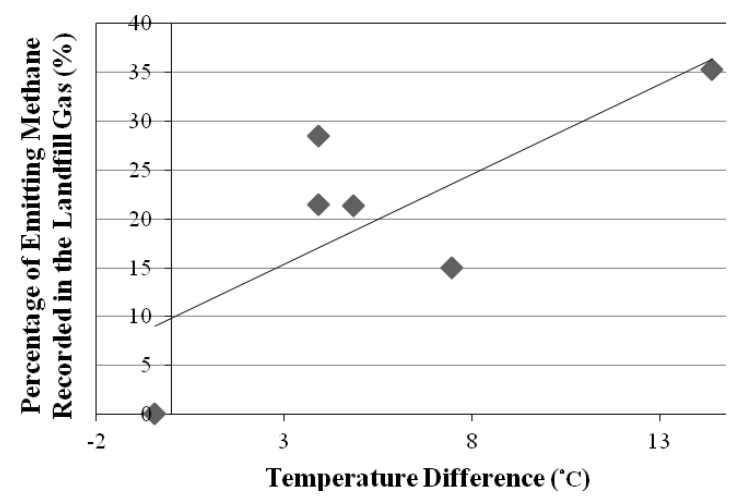

Figure 7. Relationship between the Percentage of Emitting Methane Recorded in GM-2 and the Temperature for $2008\left(\mathrm{R}^{2}\right.$ $=0.573$ )

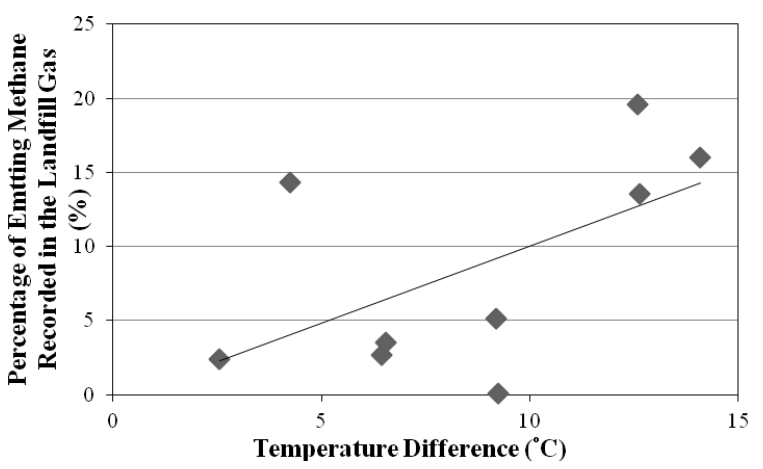

Figure 8. Relationship between the Percentage of Emitting Methane Recorded in GM-17 and the Temperature for $2007\left(\mathrm{R}^{2}\right.$ $=0.332$ )

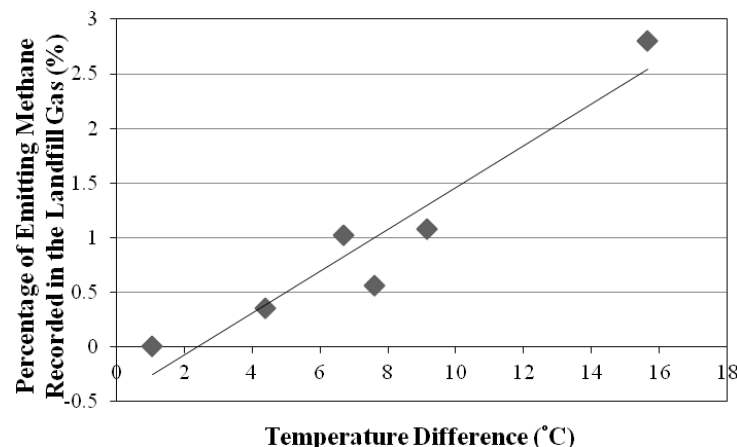

Figure 9. Relationship between the Percentage of Emitting Methane Recorded in GM-17 and the Temperature for $2008\left(\mathrm{R}^{2}\right.$ $=0.914)$

\subsection{Al-Jleeb Landfill}

The LST is used to detect suspicious dumping areas in the AlJleeb landfill from the Landsat images. Although the boundary of the Al-Jleeb landfill is known from historical records, the specific dumping areas are unknown. It is hard to locate these areas by field investigation, as most of the dumping sites are capped, and the area of the Al-Jleeb is $5.5 \mathrm{~km}^{2}$. Similar to the findings from the Trail Road landfill case study, it is observed that the LST of the landfill site is significantly higher than the air temperature as well as the LST of the surroundings.

Figure 10 plots the LST derived from the Landsat images and the corresponding air temperature in the Al-Jleeb landfill. Unlike the Trail Road landfill, it was observed that some of the LST derived from the remote sensing images are lower than the air temperature. It is worth mentioning that most of these cases occur when images are acquired in the winter (Jan. 13, 1985; Dec. 29 1987; Oct. 29, 1993; and Feb. 28, 1993) and water (waste water) was found in these areas. In the rest of the data, the LST is always higher than the air temperature by $9{ }^{\circ} \mathrm{C}$ to 16 ${ }^{\circ} \mathrm{C}$, which aligns with the findings from the Trail Road landfill. However, it seems that the landfill site located in a desert area does not have such large temperature differences, compared to the landfill site located in a mid-latitude area where the highest temperature difference can be up to $20^{\circ} \mathrm{C}$, i.e, the Trail Road landfill.

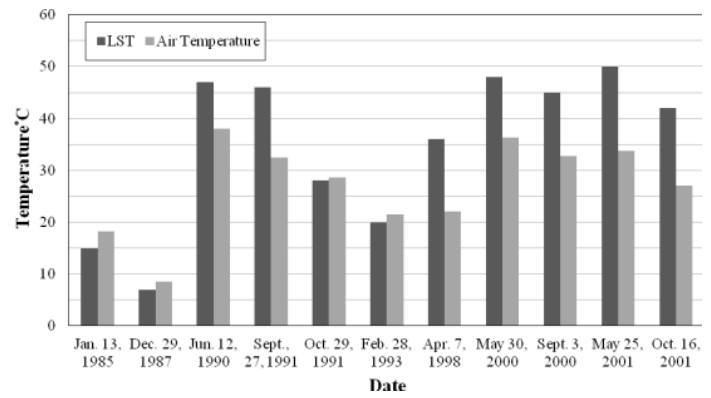

Figure 10. Comparison between the LST and the Air Temperature for the Al-Jleeb Landfill

Figure 11 illustrates the contour lines extracted from the LST at different dates). It is observed that dumping locations have always higher LST comparing to other surrounding areas regardless the season in which the images were captured. Generally, winter time has lower LST temperature comparing to summer season. This could be because of the slowdown of the decomposition process during winter due to the cold weather. It was recorded that there is an increase in the size of the areas of high temperature and also increase in the LST between the years 1985 to 1990 . Further investigation shows higher dumping activity during this period of time. It is also recorded a decrease in the LST during the period 1990-1991. This was mainly because of the Gulf war in which the dumping activities were significantly reduced. LST started to increase again by October 1991 when the dumping activities increased again after the war. Figure 12 shows the final predicted locations of the dumping sites based on the contour polygon intersection of the LST of the site.

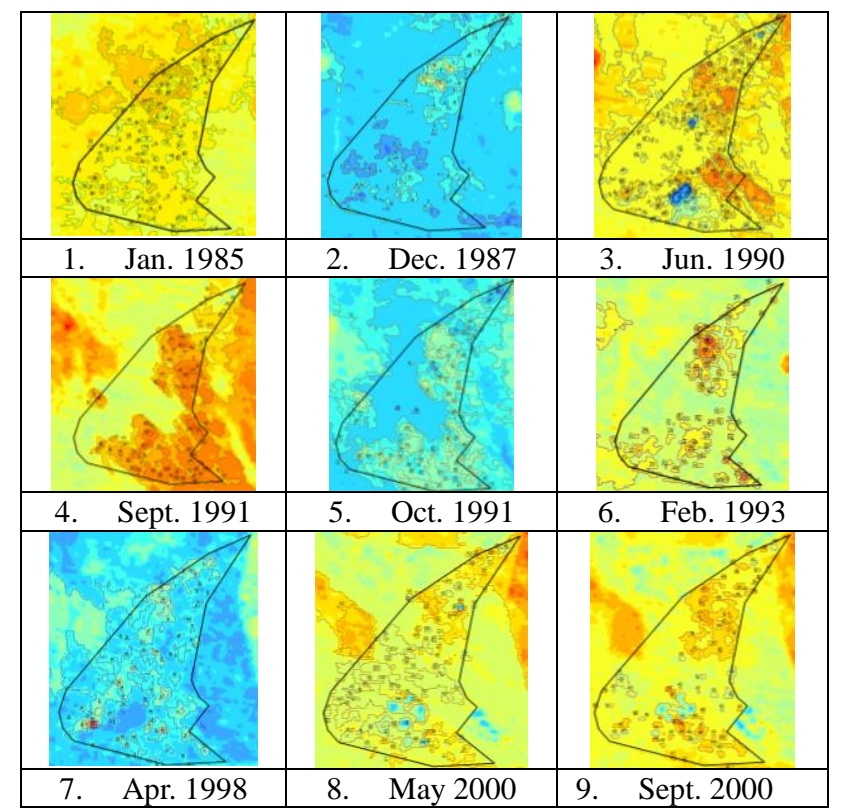



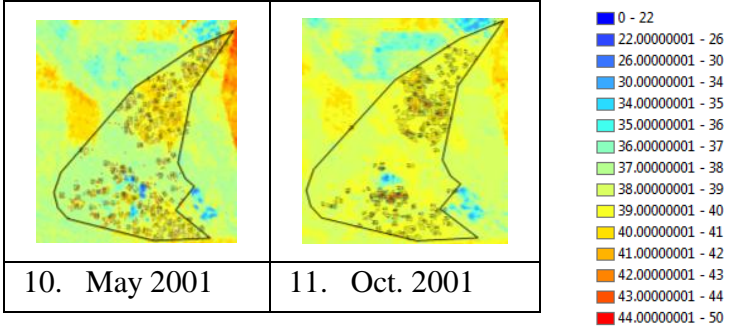

Figure 11. The multi-temporal Landsat and LST images for the Al-Jleeb Landfill

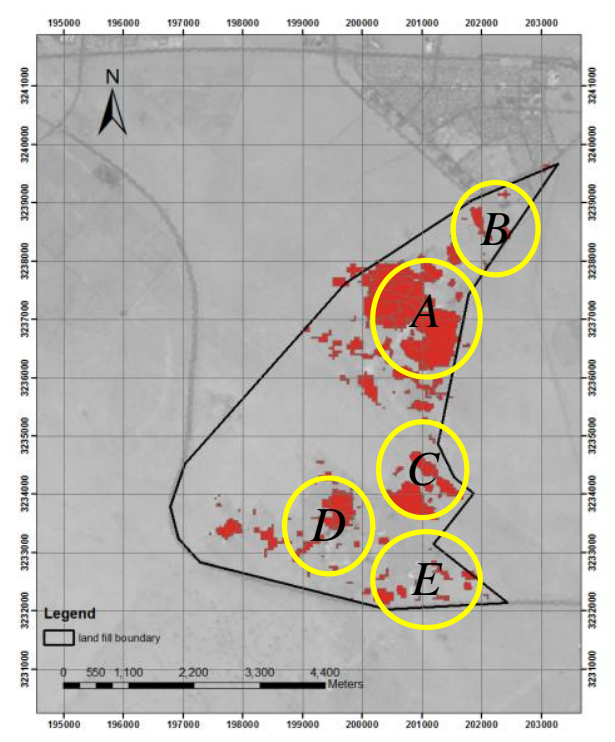

Figure 12. Suspicious Dumping Areas in the Al-Jleeb Landfill

\section{CONCLUSIONS}

In this study, 16 Landsat images (9 images acquired in 2007 and 7 images acquired in 2008) were used to study the land surface temperatures of the Trail Road landfill site and correlate the data that was extracted to ground-based measurements. The analysis shows higher LST in the landfill site areas comparing to the air temperature and the LST of the surroundings. The relationship between the emitted landfill gas (Methane $\mathrm{CH}_{4}$ ) and the LST calculated from Landsat images is investigated. It is found that LST of the landfill site has mid correlation to the amount of gases emitted from the site.

On another study area, 11 Landsat TM and $\mathrm{ETM}^{+}$images were used to detect suspicious solid waste dumping locations within Al-Jleeb site, Kuwait State. Similar to the study of the Trail Road landfill site, the Landsat images were downloaded from the USGS EarthExplorer and were atmospherically corrected using the ATCOR2 model in PCI Geomatics. The LST for the study area was computed from the thermal band (Band 6 for Landsat TM and Band 61 for Landsat $\mathrm{ETM}^{+}$). The LST images were imported into a GIS environment, and the temperature contour lines were derived from each of the images the highest temperatures for the contour lines were overlaid for each of the images to define the locations of the dumping waste. Five suspicious locations of these dumping areas were identified through the high dense overlap of the contour lines. Further ground verification is needed to confirm the finding using the LST.

\section{REFERENCES}

Biotto, G., Silvestri, S., Gobbo, L., Furlan, E., Valenti, S. and Rosselli R., 2009. GIS, multi-criteria and multi-factor spatial analysis for the probability assessment of the existence of illegal landfills. International Journal of Geographical Information Science, 23(10), pp. 1233-1244.

Dillon Consulting Limited, 2008. Trial Road landfill Site 2007 Monitoring and Operating Report, City of Ottawa, Canada.

Mirtorabi, R. 2010. Comparison between satellite images and site data for monitoring at trail road landfill. Ryerson University, M.A.Sc. Thesis, pp. 139

Nas, B., Cay, T., İşcan, F., and Berktay, A., 2010. Selection of MSW landfill site for Konya, Turkey using GIS and multicriteria evaluation. Environmental Monitoring and Assessment, 160(1-4), 491-500.

Ottavianelli, G., 2007. Synthetic Aperture Radar remote sensing for landfill monitoring. Ph.D. Thesis, Cranfield University, United Kingdom, 298 pp.

Schrapp, K. and Al-Mutairi, N. 2010. Associated health effects among residences near Jeleeb Al-Shuyoukh landfill. American Journal of Environmental Sciences, 6(2), pp. 184-190.

Silvestri, S., and Omri, M., 2008. A method for the remote sensing identification of uncontrolled landfills: formulation and validation. International Journal of Remote Sensing, 29(4), pp. 975-989.

Slonecker, T., Fisher, G.B., Aiello, D.P., and Haack. B. 2010. Visible and infrared remote imaging of hazardous water: a review. Remote Sensing, 2, pp. $2474-2508$.

Shaker, A., Faisal, K., El-Ashmawy, N., and Yan, W.Y. 2010. Effectiveness of using remote sensing techniques in monitoring landfill sites using multi-temporal Landsat satellite data. AlAzhar University Engineering Journal, 5(1), pp. 542-551.

Yahaya, O., Umoh, V. J. and Ameh, J. B. 2011. Public health implications of using water from wells located near municipal waste dump sites in parts of Zaria. Medical Practice and Review, 2(4), pp.44-49.

\section{ACKNOWLEDGEMENTS}

Special thanks go to the Environment Public Authority of Kuwait Government for the data and the information they have provided about the Al-Jleeb landfill. Special thanks also are extended to the City of Ottawa, Town of Nepean, and Dillon Consulting, Limited, for the data and information that they provided on the Trail Road landfill. This research work is partially supported by the NSERC Discovery Grant. 